\title{
SHEEHAN'S SYNDROME- A RARE DISEASE WITH TYPICAL SYMPTOMS
}

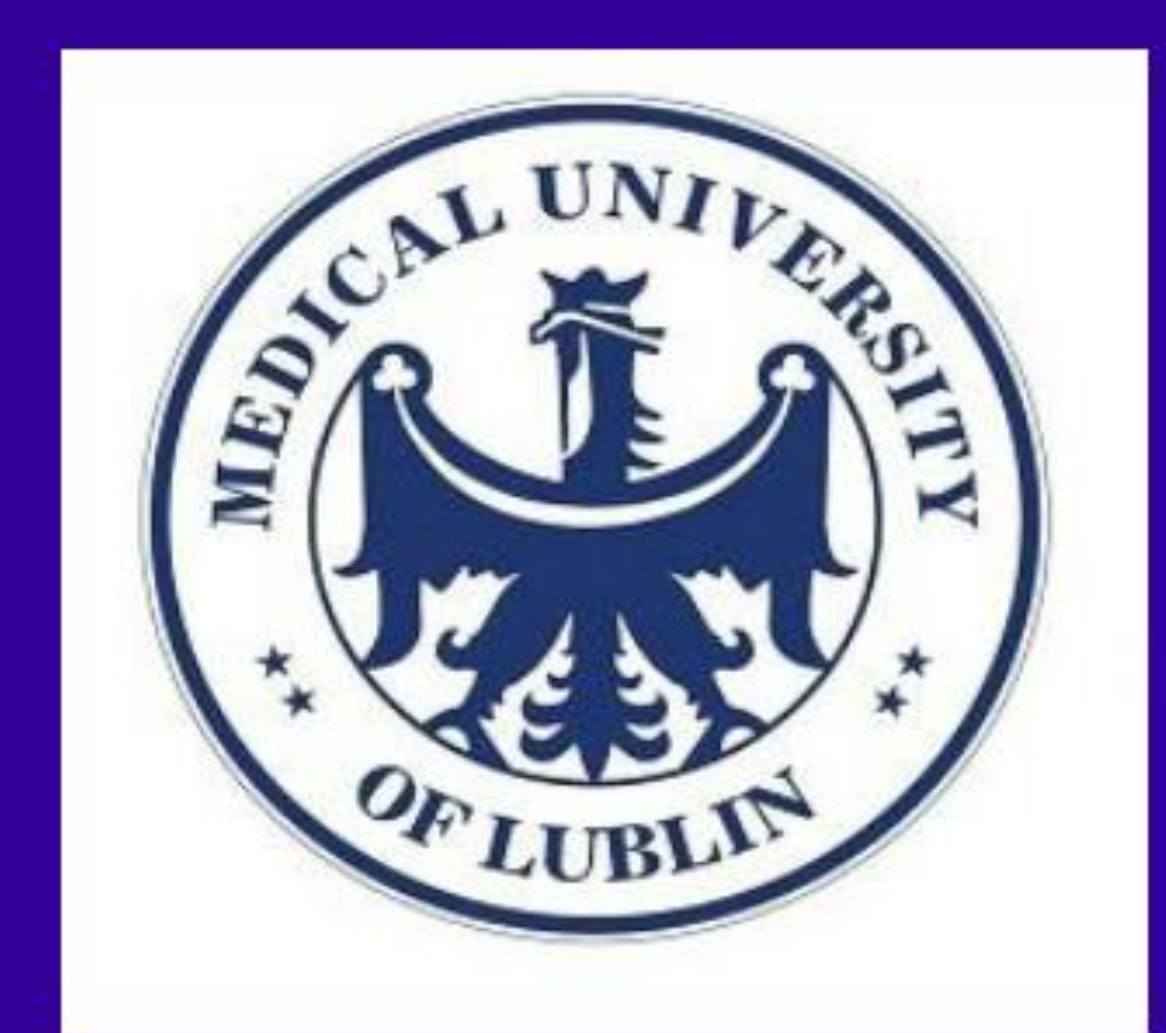

Anna M.Dąbrowska1, Jerzy S.Tarach', Agnieszka Zwolak ${ }^{1,2}$, Anna Oszywa-Chabros ${ }^{1}$

${ }^{1}$ Chair and Department of Endocrinology, Medical University of Lublin, Poland

${ }^{2}$ Chair of Internal Medicine and Department of Internal Medicine in Nursing, Medical University of Lublin, Poland

\section{INTRODUCTION}

The enlarged pituitary gland of pregnancy is susceptible to any compromise to its blood supply.

Sheehan's syndrome (SS) occurs as a result of post-partum pituitary infarction

or haemorrhage and usually leads to hypopituitarism. It can be fatal but clinical manifestations may change from one patient to another and symptoms may not occur for many years.

\section{METHODS}

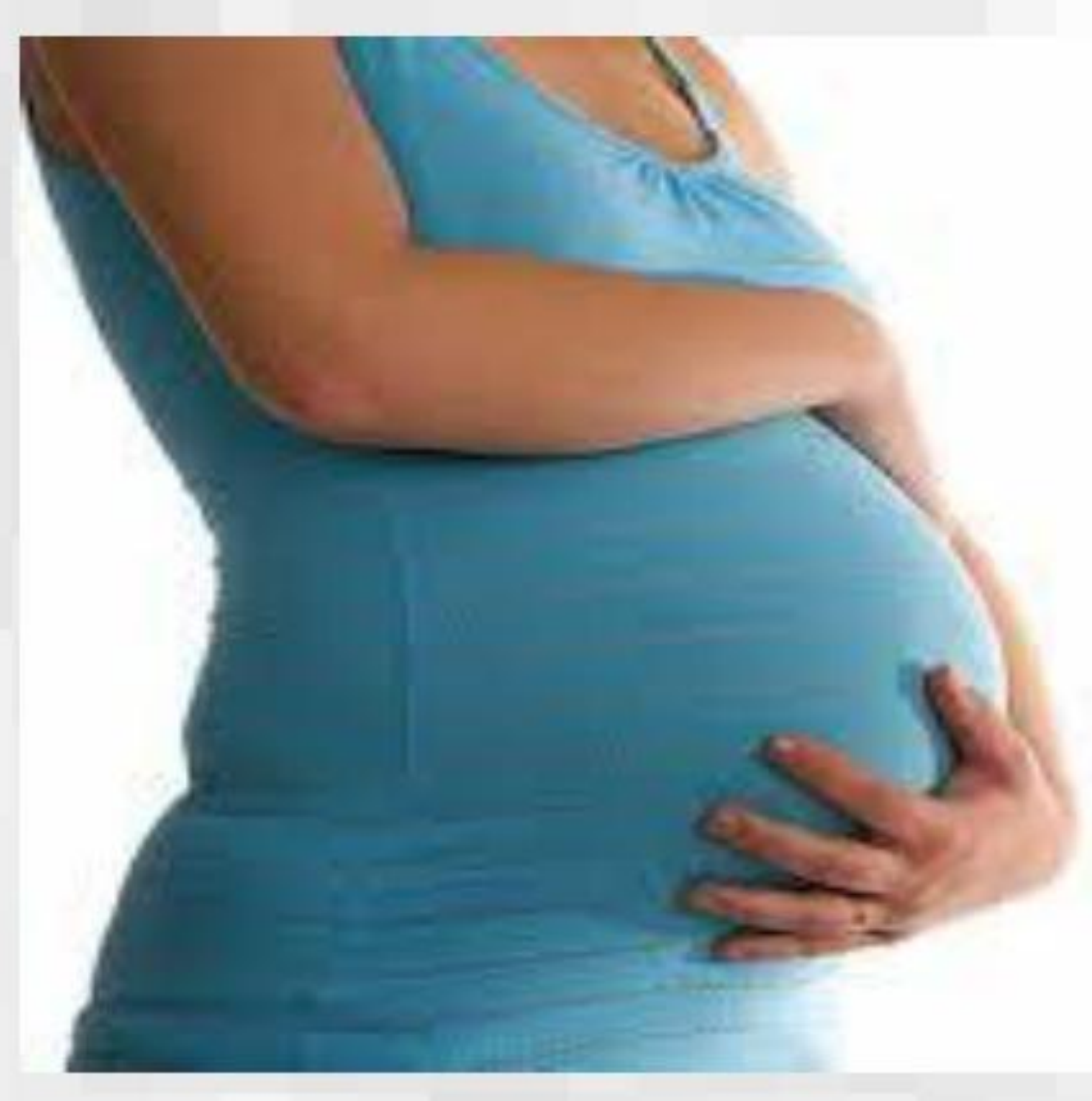

We analyzed retrospectively 5 cases of women with SS aged 26-56 years, treated at Endocrinology Department between 2003 and 2014, to describe clinical manifestations. The diagnosis of SS was made based on medical history, clinical symptoms, hormonal tests and MRI scans.

\section{RESULTS}

Mean age of the patients was $\mathbf{4 1 . 0 0} \pm \mathbf{1 2 . 3 3}$ years (range 26-56 years).

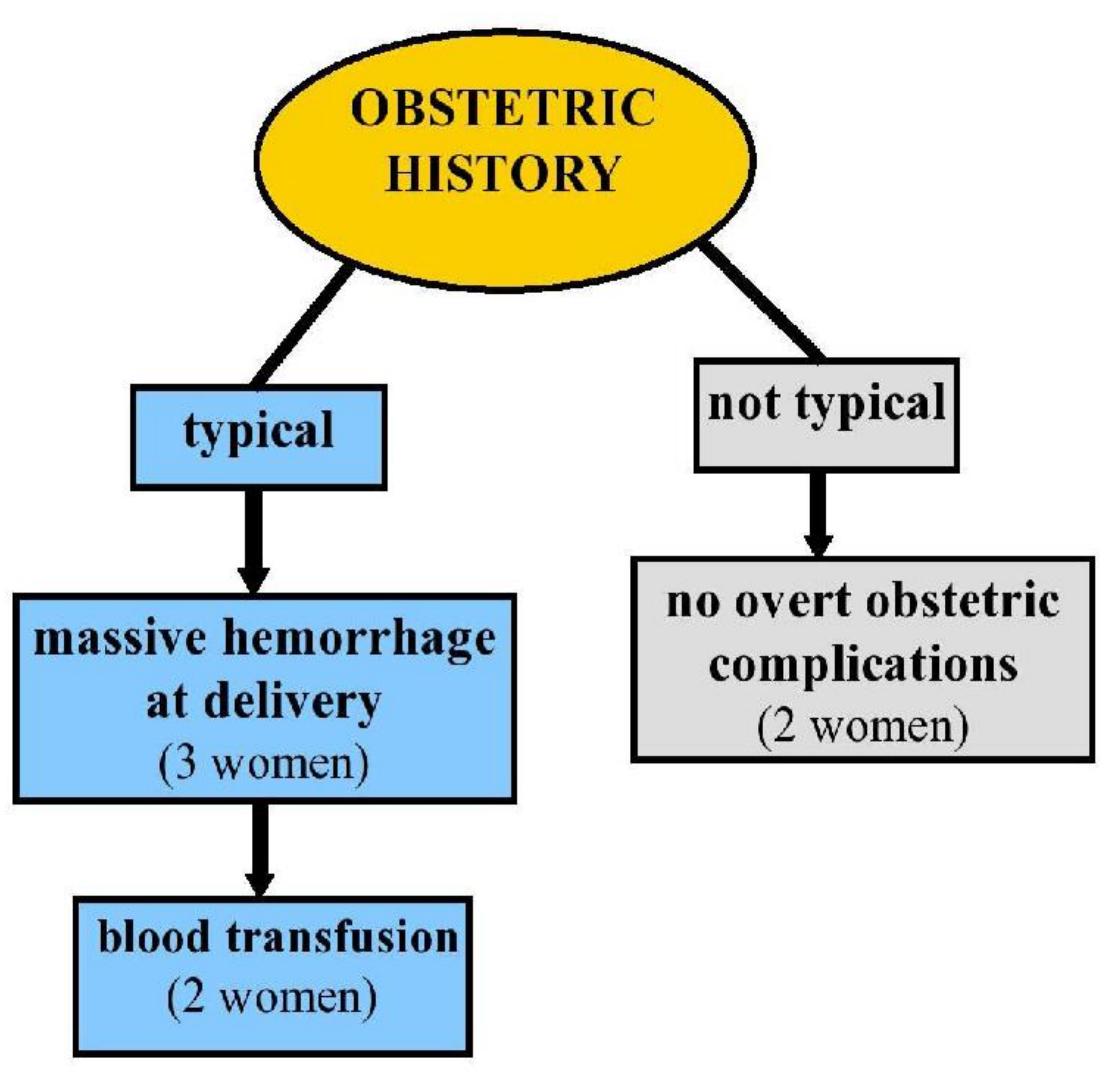

The duration between date of the last delivery and time of diagnosis was $9.82 \pm 8.85$ years (ranged from 1 month to 19 years).

The number of pregnancies was from 1 to 4.

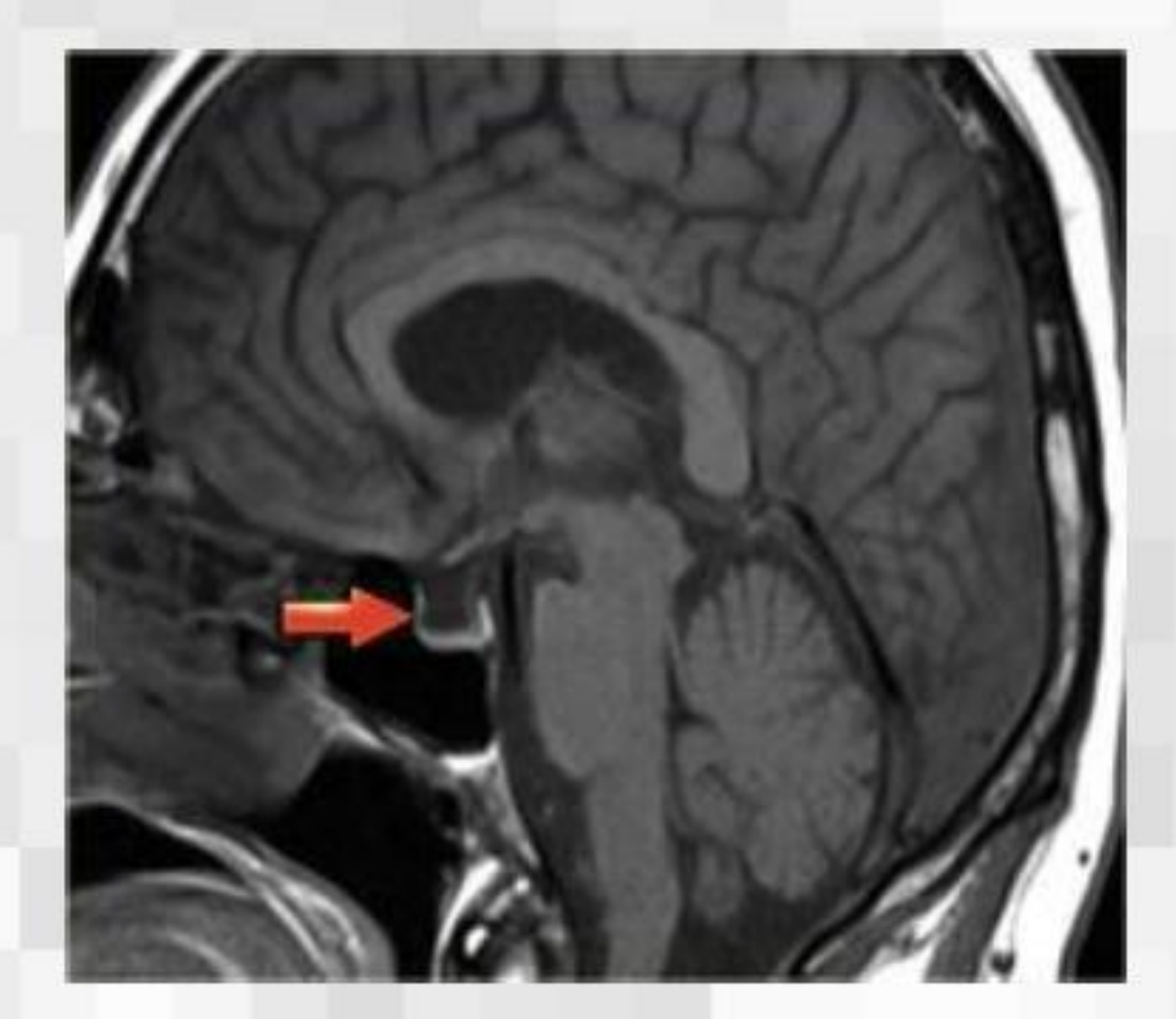

All subjects had typical physical signs of SS.

\begin{tabular}{|c|c|}
\hline SYMPTOMS & TREATMENT \\
\hline $\begin{array}{l}\text { 1. prolactin deficiency with } \\
\text { a lack of postpartum } \\
\text { milk production }\end{array}$ & - \\
\hline $\begin{array}{l}\text { 2. hypogonadotropic } \\
\text { hypogonadism with a lack } \\
\text { of menstruation following } \\
\text { delivery }\end{array}$ & $\begin{array}{l}\text { sex hormone } \\
\text { replacement }\end{array}$ \\
\hline $\begin{array}{l}\text { 3. secondary hypothyroidism } \\
\text { (partial or total) }\end{array}$ & 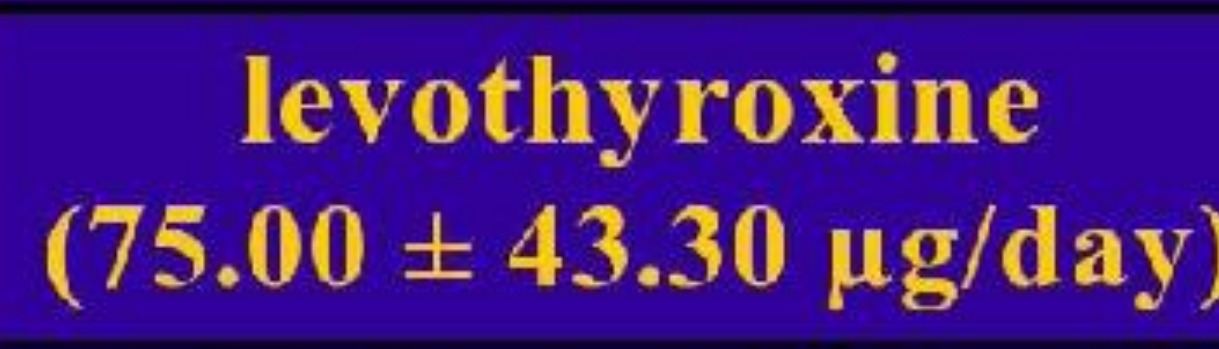 \\
\hline $\begin{array}{l}\text { 4. secondary adrenal cortex } \\
\text { failure (partial or total) }\end{array}$ & $\begin{array}{c}\text { hydrocortisone } \\
(25.00 \pm 7.07 \mathrm{mg} / \mathrm{day})\end{array}$ \\
\hline $\begin{array}{l}\text { 5. growth hormone } \\
\text { deficiency }\end{array}$ & - \\
\hline $\begin{array}{l}\text { 6. diabetes insipidus } \\
\text { (transient- only in } 1 \\
\text { woman) }\end{array}$ & $\begin{array}{c}\text { desmopressin } \\
\text { (120 } \mu \mathrm{g} / \text { day for } 17 \\
\text { months) }\end{array}$ \\
\hline
\end{tabular}

MRI scans revealed total or partially empty sella in 3 women and small (beyond the normal range) pituitary gland in 2 cases.

CONCLUSION: Although SS is not a common disease, it should be remembered about concerning women with pituitary insufficiency developing at different times after delivery. 